\title{
Observations of organic and inorganic chlorinated compounds and their contribution to chlorine radical concentrations in an urban environment in northern Europe during the wintertime
}

\author{
Michael Priestley $^{1}$, Michael le Breton ${ }^{1, a}$, Thomas J. Bannan ${ }^{1}$, Stephen D. Worrall ${ }^{1, b}$, Asan Bacak ${ }^{1}$, \\ Andrew R. D. Smedley ${ }^{1, c}$, Ernesto Reyes-Villegas ${ }^{1}$, Archit Mehra ${ }^{1}$, James Allan ${ }^{1,2}$, Ann R. Webb ${ }^{1}$, \\ Dudley E. Shallcross ${ }^{3}$, Hugh Coe ${ }^{1}$, and Carl J. Percival ${ }^{1, \mathrm{~d}}$ \\ ${ }^{1}$ Centre for Atmospheric Science, School of Earth and Environmental Sciences, University of Manchester, \\ Manchester, M13 9PL, UK \\ ${ }^{2}$ National Centre for Atmospheric Science, University of Manchester, Manchester, M13 9PL, UK \\ ${ }^{3}$ School of Chemistry, The University of Bristol, Cantock's Close BS8 1TS, UK \\ ${ }^{a}$ now at: Department of Chemistry and Molecular Biology, University of Gothenburg, 41296 Gothenburg, Sweden \\ ${ }^{b}$ now at: School of Materials, University of Manchester, Manchester, M13 9PL, UK \\ ${ }^{c}$ now at: School of Mathematics, University of Manchester, Manchester, M13 9PL, UK \\ ${ }^{d}$ now at: Jet Propulsion Laboratory, 4800 Oak Grove Drive, Pasadena, CA 91109, USA
}

Correspondence: Carl Percival (carl.j.percival@jpl.nasa.gov)

Received: 6 March 2018 - Discussion started: 7 March 2018

Revised: 27 July 2018 - Accepted: 28 August 2018 - Published: 21 September 2018

\begin{abstract}
A number of inorganic (nitryl chloride, $\mathrm{ClNO}_{2}$; chlorine, $\mathrm{Cl}_{2}$; and hypochlorous acid, $\mathrm{HOCl}$ ) and chlorinated, oxygenated volatile organic compounds (ClOVOCs) have been measured in Manchester, UK during October and November 2014 using time-of-flight chemical ionisation mass spectrometry (ToF-CIMS) with the $\mathrm{I}^{-}$reagent ion. ClOVOCs appear to be mostly photochemical in origin, although direct emission from vehicles is also suggested. Peak concentrations of $\mathrm{ClNO}_{2}, \mathrm{Cl}_{2}$ and $\mathrm{HOCl}$ reach 506, 16 and 9 ppt respectively. The concentrations of $\mathrm{ClNO}_{2}$ are comparable to measurements made in London, but measurements of ClOVOCs, $\mathrm{Cl}_{2}$ and $\mathrm{HOCl}$ by this method are the first reported in the $\mathrm{UK}$. Maximum $\mathrm{HOCl}$ and $\mathrm{Cl}_{2}$ concentrations are found during the day and $\mathrm{ClNO}_{2}$ concentrations remain elevated into the afternoon if photolysis rates are low. $\mathrm{Cl}_{2}$ exhibits a strong dependency on shortwave radiation, further adding to the growing body of evidence that it is a product of secondary chemistry. However, night-time emission is also observed. The contribution of $\mathrm{ClNO}_{2}, \mathrm{Cl}_{2}$ and ClOVOCs to the chlorine radical budget suggests that $\mathrm{Cl}_{2}$ can be a greater source of $\mathrm{Cl}$ than $\mathrm{ClNO}_{2}$, contributing $74 \%$ of the $\mathrm{Cl}$ radicals produced on a high radiant-flux day. In contrast, on a low radiant-flux day, this drops to $14 \%$, as both $\mathrm{Cl}_{2}$ produc-
\end{abstract}

tion and loss pathways are inhibited by reduced photolysis rates. This results in $\mathrm{ClNO}_{2}$ making up the dominant fraction $(83 \%)$ on low radiant-flux days, as its concentrations are still high. As most ClOVOCs appear to be formed photochemically, they exhibit a similar dependence on photolysis, contributing $3 \%$ of the $\mathrm{Cl}$ radical budget observed here.

\section{Introduction}

Oxidation controls the fate of many atmospheric trace gases. For example, increasing the oxidation state of a given species may increase its deposition velocity (Nguyen et al., 2015) or solubility (Carlton et al., 2006) and reduce its volatility (Carlton et al., 2006), all of which act to reduce the atmospheric lifetime of that species and can lead to the formation of secondary material such as secondary organic aerosol (SOA) or ozone $\left(\mathrm{O}_{3}\right)$. As the identity of the chemical species change with oxidation, intrinsic and diverse properties of the chemical species are altered, influencing their toxicity (Borduas et al., 2015) and their impact on the environment, 
e.g. cloud-particle nucleating efficiency (Ma et al., 2013) or global warming potential (Boucher et al., 2009).

The hydroxyl radical $(\mathrm{OH})$ is considered the most important daytime atmospheric oxidant due to its ubiquity and high reactivity, with an average tropospheric concentration of $10^{6}$ molecules $\mathrm{cm}^{-3}$ (Heal et al., 1995). However, rate coefficients for the reaction of the chlorine radical $(\mathrm{Cl})$ can be 2 orders of magnitude larger than those for $\mathrm{OH}$ (Spicer et al., 1998), indicating that lower $\mathrm{Cl}$ concentrations of $1 \times 10^{4}$ atoms $\mathrm{cm}^{-3}$ that are estimated to exist in urban areas (e.g. Bannan et al., 2015) can be just as significant in their contribution to oxidation.

Cl-initiated oxidation of volatile organic compounds (VOCs) forms chlorinated analogues of the OH-initiated oxidation products, via addition Eq. (1) or hydrogen abstraction Eq. (2), forming $\mathrm{HCl}$ that may react with $\mathrm{OH}$ to regenerate $\mathrm{Cl}$. Subsequent peroxy radicals formed through $\mathrm{Cl}$ oxidation can take part in the $\mathrm{HO}_{x}$ cycle and contribute to the enhanced formation of $\mathrm{O}_{3}$ and SOA (Wang and Ruiz, 2017). This is represented by the following;

$$
\begin{aligned}
& R+X \stackrel{\mathrm{O}_{2}}{\longrightarrow} R(X) \mathrm{OO} \cdot \\
& R \mathrm{H}+\mathrm{X} \stackrel{\mathrm{O}_{2}}{\longrightarrow} R \mathrm{OO} \cdot+H \mathrm{X},
\end{aligned}
$$

where $X$ is $\mathrm{OH}$ or $\mathrm{Cl}$.

Nitryl chloride $\left(\mathrm{ClNO}_{2}\right)$ is a major reservoir of $\mathrm{Cl}$ that is produced by aqueous reactions between particulate chloride $\left(\mathrm{Cl}^{-}\right)$and nitrogen pentoxide $\left(\mathrm{N}_{2} \mathrm{O}_{5}\right)$, as seen in Eq. (4) and Eq. (6). Gaseous $\mathrm{ClNO}_{2}$ is produced throughout the night and is typically photolysed at dawn before $\mathrm{OH}$ concentrations reach their peak, as in Eq. (6). This early morning release of $\mathrm{Cl}$ induces oxidation earlier in the day and has been shown to increase maximum $8 \mathrm{~h}$ mean $\mathrm{O}_{3}$ concentrations by up to $7 \mathrm{ppb}$ under moderately elevated $\mathrm{NO}_{x}$ levels (Sarwar et al., 2014). Typical $\mathrm{ClNO}_{2}$ concentrations measured in urban regions range from $10 \mathrm{~s}$ of ppt to $1000 \mathrm{~s}$ of ppt. Mielke et al. (2013) measured a maximum of $3.6 \mathrm{ppb}(0.04 \mathrm{~Hz})$ during the summertime in Los Angeles, with maximum sunrise concentrations of 800 ppt. Bannan et al. (2015) measured a maximum concentration of $724 \mathrm{ppt}(1 \mathrm{~Hz})$ at an urban background site in London during summer. They state that in some instances, $\mathrm{ClNO}_{2}$ concentrations increase after sunrise and attribute this to the influx of air masses with higher $\mathrm{ClNO}_{2}$ concentrations by either advection or from the collapse of the residual mixing layer. In urban environments where $\mathrm{NO}_{x}$ emission and subsequent $\mathrm{N}_{2} \mathrm{O}_{5}$ production is likely, $\mathrm{Cl}^{-}$may be the limiting reagent in the formation of $\mathrm{ClNO}_{2}$ if excess $\mathrm{NO}$ does not reduce $\mathrm{NO}_{3}$ as seen in Eq. (3) before $\mathrm{N}_{2} \mathrm{O}_{5}$ is produced (e.g. Bannan et al., 2015). Whilst the distance from a marine source of $\mathrm{Cl}^{-}$may explain low, inland concentrations Faxon et al., 2015), the long-range transport of marine air can elevate inland $\mathrm{ClNO}_{2}$ concentrations (Phillips et al., 2012) and the long-range transport of polluted plumes to a marine location can also elevate $\mathrm{ClNO}_{2}$ concentrations (e.g.
Bannan et al., 2017). These processes may be represented by the following equations;

$$
\begin{aligned}
& \mathrm{NO}_{3}+\mathrm{NO} \longrightarrow 2 \mathrm{NO}_{2}, \\
& \mathrm{NO}_{3}+\mathrm{NO}_{2} \longrightarrow \mathrm{N}_{2} \mathrm{O}_{5(g)} \longrightarrow \mathrm{N}_{2} \mathrm{O}_{5(\text { aq })} \\
& \mathrm{Cl}^{-}+\mathrm{N}_{2} \mathrm{O}_{5} \longrightarrow \mathrm{ClNO}_{2}+\mathrm{NO}_{3}^{-}, \\
& \mathrm{ClNO}_{2(\mathrm{aq})} \longrightarrow \mathrm{ClNO}_{2(g)} \stackrel{J_{\mathrm{ClNO}_{2}}}{\longrightarrow} \mathrm{Cl}+\mathrm{NO}_{2} .
\end{aligned}
$$

The anthropogenic emission of molecular chlorine is identified as another inland source of $\mathrm{Cl}^{-}$in the US (e.g. Thornton et al., 2010; Riedel et al., 2012) and in China (e.g. Wang et al., 2017; Liu et al., 2017), where some of the highest concentrations 3.0-4.7 ppb have been recorded. As well as industrial processes, the suspension of road salt used to melt ice on roads during the winter has been suggested as a large source of anthropogenic $\mathrm{Cl}^{-}$Mielke et al., 2016). This wintertimeonly source, combined with reduced nitrate radical photolysis, is expected to yield greater $\mathrm{ClNO}_{2}$ concentrations at this time of the year (Mielke et al., 2016).

The photolysis of molecular chlorine $\left(\mathrm{Cl}_{2}\right)$ is another potential source of $\mathrm{Cl}$. Numerous heterogeneous formation mechanisms leading to $\mathrm{Cl}_{2}$ from particles containing $\mathrm{Cl}^{-}$are known. These include the reaction of $\mathrm{Cl}^{-}$and $\mathrm{OH}$ (Vogt et al., 1996), which may originate from the photolysis of $\mathrm{O}_{3(\mathrm{aq})}$ (Oum, 1998) or from the reactive uptake of $\mathrm{ClNO}_{2}$ (Leu et al., 1995), $\mathrm{ClONO}_{2}$ (Deiber et al., 2004) or $\mathrm{HOCl}$ (Eigen and Kustin, 1962) to acidic $\mathrm{Cl}^{-}$containing particles. Thornton et al. (2010) also suggest that inorganic $\mathrm{Cl}$ reservoirs such as $\mathrm{HOCl}$ and $\mathrm{ClONO}_{2}$ may also enhance the $\mathrm{Cl}$ concentration, potentially accounting for the shortfall in the global burden (8-22 $\mathrm{Tg} \mathrm{yr}^{-1}$ source from $\mathrm{ClNO}_{2}$ and $25-35 \mathrm{Tg} \mathrm{yr}^{-1}$ as calculated from methane isotopes). This may be direct through photolysis or indirect through heterogenous reactions with $\mathrm{Cl}^{-}$on acidic aerosol.

Globally, $\mathrm{Cl}_{2}$ concentrations are highly variable. In the marine atmosphere, concentrations of up to $35 \mathrm{ppt}$ have been recorded (Lawler et al., 2011), whereas at urban costal sites in the US, concentrations on the order of 100s ppt have been measured (Keene et al., 1993; Spicer et al., 1998). Sampling urban outflow, Riedel et al. (2012) measure a maximum of $200 \mathrm{ppt} \mathrm{Cl}_{2}$ from plumes and mean concentrations of $10 \mathrm{ppt}$ on a ship in the LA basin. Maximum mixing ratios of up to $65 \mathrm{ppt}$ have also been observed in the continental US (Mielke et al., 2011).

More interestingly, these studies (Keene et al., 1993; Lawler et al., 2011; Mielke et al., 2011; Spicer et al., 1998) report maximum $\mathrm{Cl}_{2}$ concentrations at night and minima during the day. However, there is a growing body of evidence suggesting that daytime $\mathrm{Cl}_{2}$ may also be observed. Although the primary emission may be one source of daytime $\mathrm{Cl}_{2}$ (Mielke et al., 2011), others demonstrate that the diurnal characteristics of the $\mathrm{Cl}_{2}$ time series have a broader signal suggestive of continuous processes rather than intermittent 
signals typically associated with sampling emission sources under turbulent conditions.

In a clean marine environment Liao et al. (2014) observe maximum $\mathrm{Cl}_{2}$ concentrations of $400 \mathrm{ppt}$ attributed to emissions from a local snow pack source. A maximum was measured during the morning and evening with a local minimum during midday caused by photolysis. They also describe negligible night-time concentrations, with significant loss attributed to deposition. Faxon et al. (2015) measured $\mathrm{Cl}_{2}$ with a time-of-flight chemical ionisation mass spectrometry (ToF-CIMS) recording a maximum during the afternoon of $4.8 \mathrm{ppt}(0.0016 \mathrm{~Hz})$ and suggesting a local precursor primary source of $\mathrm{Cl}_{2}$ that is potentially soil emission, with further heterogeneous chemistry producing $\mathrm{Cl}_{2}$. At a rural site in northern China, Liu et al. (2017) measured mean concentrations of $\mathrm{Cl}_{2}$ of $100 \mathrm{ppt}$ and a maximum of $450 \mathrm{ppt}$, peaking during the day; they also report $480 \mathrm{ppt}$ observed in an urban environment in the US during summer. They attribute powergeneration facilities burning coal as the source.

Another potential source of $\mathrm{Cl}$ to the atmosphere is the photolysis of chlorinated organic compounds (ClVOCs, chlorocarbons, organochlorides) that are emitted from both natural (biomass burning, oceanic and biogenic emission) (e.g. Yokouchi et al., 2000) and anthropogenic sources (e.g. Butler, 2000). Whilst many ClVOCs are only considered chemically important in the stratosphere, those that are photochemically labile in the troposphere, e.g. methyl hypochlorite $\left(\mathrm{CH}_{3} \mathrm{OCl}\right)$, whose absorption cross section is non-negligible at wavelengths as long as $460 \mathrm{~nm}$ (Crowley et al., 1994), can act as a source of $\mathrm{Cl}$ and take part in oxidative chemistry.

Photolysis of ClVOCs have been postulated to contribute $0.1-0.5 \times 10^{3}$ atoms $\mathrm{cm}^{-3}$ globally to the $\mathrm{Cl}$ budget of the boundary layer (Hossaini et al., 2016), although on much smaller spatial and temporal scales, the variance in this estimate is likely to be large. Very few data exist on the concentrations, sources and spatial extent of oxygenated ClVOCs (ClOVOCs) and their contribution to the $\mathrm{Cl}$ budget.

The ToF-CIMS is a highly selective and sensitive instrument with high mass accuracy and a resolution $(\mathrm{m} / \mathrm{dm}$ $\sim 4000$ ) that is capable of detecting a suite of chlorinated compounds, including $\mathrm{HOCl}$ and organic chlorine (Le Breton et al., 2018) as well as other oxygenated chlorine species and chloroamines (Wong et al., 2017). Here we use the ToFCIMS with the $\mathrm{I}^{-}$reagent ion to characterise the sources of chlorine and estimate their contribution to $\mathrm{Cl}$ concentrations in the wintertime in Manchester, UK.

\section{Methodology/experiment}

Full experimental details and a description of meteorological and air quality measurements can be found in Priestley et al. (2018). A time-of-flight chemical ionisation mass spectrometer (ToF-CIMS) (Lee et al., 2014b) using iodide reagent ions was used to sample ambient air between 29 October and 11 November 2014 at the University of Manchester's southern campus, approximately $1.5 \mathrm{~km}$ south of Manchester city centre, UK $\left(53.467^{\circ} \mathrm{N}, 2.232^{\circ} \mathrm{W}\right)$ and $55 \mathrm{~km}$ east of the Irish Sea. The sample loss to the $1 \mathrm{~m}$ long $3 / 4^{\prime \prime}$ Perfluoroalkoxy alkane (PFA) inlet was minimised by using a fast inlet pump inducing a flow rate of 15 standard litres per minute (slm) which was subsampled by the ToF-CIMS. Backgrounds were taken every $6 \mathrm{~h}$ for $20 \mathrm{~min}$ by overflowing dry $\mathrm{N}_{2}$ and were applied consecutively. The overflowing of dry $\mathrm{N}_{2}$ will have a small effect on the sensitivity of the instrument to those compounds whose detection is water dependent. Here we find that due to the low instrumental backgrounds, the absolute error remains small and is an acceptable limitation in order to measure a vast suite of different compounds for which no best practice backgrounding method has been established. Whilst backgrounds were taken infrequently, they are of a comparable frequency to those used in previous studies where similar species are measured (Lawler et al., 2011; Osthoff et al., 2008; Phillips et al., 2012). The stability of the background responses, i.e. for $\mathrm{Cl}_{2} 0.16 \pm 0.07(1 \sigma) \mathrm{ppt}$, and the stability of the instrument diagnostics with respect to the measured species suggest that they effectively capture the true instrumental background.

Formic acid was calibrated throughout the campaign and post campaign. Very little deviation in the formic acid calibrations was observed. The mean average sensitivity was $30.66 \pm 1.90(1 \sigma) \mathrm{Hz} \mathrm{ppt}^{-1}$. A number of chlorinated species were calibrated post campaign using a variety of different methods, and relative calibration factors were applied based on measured instrument sensitivity to formic acid as has been performed previously (e.g. Le Breton et al., 2014a, 2017; Bannan et al., 2015). A summary of calibration procedures and species calibrated are described below. All data from between 16:30 LT on 5 November and 00:00 LT on 7 November have been removed to prevent the interference of a largescale anthropogenic biomass burning event (Guy Fawkes Night) on these analyses.

\subsection{Calibrations}

We calibrate a number of species by overflowing the inlet with various known concentrations of gas mixtures (Le Breton et al., 2012), including molecular chlorine $\left(\mathrm{Cl}_{2}, 99.5 \%\right.$ purity, Aldrich), formic acid (98/100\%, Fisher) and acetic acid (glacial, Fisher) by making known mixtures (in $\mathrm{N}_{2}$ ) and flowing 0-20 standard cubic centimetres per minute $(\mathrm{sccm})$ into a $3 \operatorname{sim~} \mathrm{N}_{2}$ dilution flow that is subsampled. The $\mathrm{Cl}_{2}$ calibration factor is $4.6 \mathrm{~Hz} \mathrm{ppt}^{-1}$.

As all chlorinated VOCs we observe are oxygenated we assume the same sensitivity found for 3-chloropropionic acid $\left(10.32 \mathrm{~Hz} \mathrm{ppt}^{-1}\right)$ for the rest of the organic chlorine species detected. Chloropropionic acid (Aldrich) was calibrated following the methodology of Lee et al. (2014). A known quantity of chloropropionic acid was dissolved in methanol 
(Aldrich) and a known volume was doped onto a filter. The filter was slowly heated to $200^{\circ} \mathrm{C}$ to ensure the total desorption of the calibrant whilst $3 \mathrm{slm} \mathrm{N}_{2}$ flowed over it. This was repeated several times. A blank filter was first used to determine the background.

$\mathrm{ClNO}_{2}$ was calibrated by the method described by Kercher et al. (2009) with $\mathrm{N}_{2} \mathrm{O}_{5}$ synthesised following the methodology described by Le Breton et al. (2014)a, giving a calibration factor of $4.6 \mathrm{~Hz} \mathrm{ppt}^{-1}$. Excess $\mathrm{O}_{3}$ is generated by flowing $200 \mathrm{sccm} \mathrm{O}_{2}$ (BOC) through an ozone generator (BMT, $802 \mathrm{~N})$ and into a $5 \mathrm{~L}$ glass volume containing $\mathrm{NO}_{2}(\sigma$, $>99.5 \%)$. The outflow from this reaction vessel is cooled in a cold trap held at $-78^{\circ} \mathrm{C}(195 \mathrm{~K})$ by a dry ice and glycerol mixture where $\mathrm{N}_{2} \mathrm{O}_{5}$ is condensed and frozen. The trap is allowed to reach room temperature and the flow is reversed, where it is then condensed in a second trap held at $195 \mathrm{~K}$. This process is repeated several times to purify the mixture. The system is first purged by flowing $\mathrm{O}_{3}$ for $10 \mathrm{~min}$ before use. To ascertain the $\mathrm{N}_{2} \mathrm{O}_{5}$ concentration on the line, the flow is diverted through heated line to decompose the $\mathrm{N}_{2} \mathrm{O}_{5}$ and into to a Thermo Scientific $42 \mathrm{i} \mathrm{NO} x$ analyser, where it is detected as $\mathrm{NO}_{2}$. It is known that the Thermo Scientific 42i $\mathrm{NO}_{x}$ analyser suffers from interferences from $\mathrm{NO}_{y}$ species, indicating that this method could cause an underestimation of the $\mathrm{ClNO}_{2}$ concentrations reported here. Based on previous studies (e.g. Le Breton et al., 2014; Bannan et al., 2017) where comparisons with a broad-beam cavity-enhancement absorption spectrometer (BBCEAS) have been made, good agreement has been found between co-located $\mathrm{N}_{2} \mathrm{O}_{5}$ measurements. We feel that this calibration method works well, likely in part due to the high purity of the $\mathrm{N}_{2} \mathrm{O}_{5}$ synthesised and because the possible interference of $\mathrm{NO}_{y}$ on the $\mathrm{NO}_{x}$ analyser during this calibration is considered negligible. The $\mathrm{N}_{2} \mathrm{O}_{5}$ is passed over a salt slurry where excess chloride may react to produce $\mathrm{ClNO}_{2}$. The drop in the $\mathrm{N}_{2} \mathrm{O}_{5}$ signal is equated to the rise in $\mathrm{ClNO}_{2}$, as the stoichiometry of the reaction is $1: 1$. The conversion efficiency of $\mathrm{N}_{2} \mathrm{O}_{5}$ to $\mathrm{ClNO}_{2}$ over wet $\mathrm{NaCl}$ is known to vary by $60 \%-100 \%$ (Hoffman et al., 2003; Roberts et al., 2008). Here we follow the methodology of Osthoff et al. (2008) and Kercher et al. (2009) that ensures that conversion is $100 \%$ efficient, so we assume a $100 \%$ yield in this study.

We developed a secondary novel method to quantify $\mathrm{ClNO}_{2}$ by cross-calibration with a turbulent flow tube chemical ionisation mass spectrometer (TF-CIMS) (Leather et al., 2012). Chlorine atoms were produced by combining a $2.0 \mathrm{slm}$ flow of He with a $0-20 \mathrm{sccm}$ flow of $1 \% \mathrm{Cl}_{2}$, which was then passed through a microwave discharge produced by a surfatron (Sairem) cavity operating at $100 \mathrm{~W}$. The $\mathrm{Cl}$ atoms were titrated via a constant flow of $20 \mathrm{sccm} \mathrm{NO} 2(99.5 \%$ purity $\mathrm{NO}_{2}$ cylinder, Aldrich) from a diluted (in $\mathrm{N}_{2}$ ) gas mix to which the TF-CIMS has been calibrated. This flow is carried in $52 \mathrm{slm} \mathrm{N}_{2}$ that is purified by flowing through two heated molecular sieve traps. This flow is subsampled by the ToF-CIMS where the I.ClNO ${ }_{2}^{-}$adduct is measured. The TF-
CIMS is able to quantify the concentration of $\mathrm{ClNO}_{2}$ generated in the flow tube as the equivalent drop in $\mathrm{NO}_{2}^{-}$signal. This indirect measurement of $\mathrm{ClNO}_{2}$ is similar in its methodology to $\mathrm{ClNO}_{2}$ calibration by quantifying the loss of $\mathrm{N}_{2} \mathrm{O}_{5}$ reacted with $\mathrm{Cl}^{-}$(e.g. Kercher et al., 2009). We do not detect an increase in $\mathrm{I}_{\text {. }} \mathrm{Cl}_{2}$ signal from this calibration and so rule out the formation of $\mathrm{Cl}_{2}$ from inorganic species in our inlet due to unknown chemistry occurring in the IMR. The TF-CIMS method gives a calibration factor $58 \%$ greater than that of the $\mathrm{N}_{2} \mathrm{O}_{5}$ synthesis method. The $\mathrm{Cl}$ atom titration method assumes a $100 \%$ conversion to $\mathrm{ClNO}_{2}$ and does not take into account any $\mathrm{Cl}$ atom loss, which will lead to a reduced $\mathrm{ClNO}_{2}$ concentration and thus a greater calibration factor. Also, the method assumes a $100 \%$ sampling efficiency between the TF-CIMS and ToF-CIMS; again this could possibly lead to an increased calibration factor. Whilst the new method of calibration is promising, we assume that the proven method developed by Kercher et al. (2009) is the correct calibration factor and assign an error of $50 \%$ to that calibration factor. We feel that the difference between the two methods is taken into account by our measurement uncertainty.

We calibrate $\mathrm{HOCl}$ using the methodology described by Foster et al. (1999) giving a calibration factor of $9.22 \mathrm{~Hz} \mathrm{ppt}^{-1} .100 \mathrm{sccm} \mathrm{N}_{2}$ is flowed through a fritted bubbler filled with $\mathrm{NaOCl}$ solution (min $8 \%$ chlorine, Fisher) that meets a dry $1.5 \mathrm{slm} \mathrm{N}_{2}$ flow, with the remaining flow made up of humidified ambient air, generating the $\mathrm{HOCl}$ and $\mathrm{Cl}_{2}$ signal measured on the ToF-CIMS. The flow from the bubbler is diverted through a condensed $\mathrm{HCl}(\sigma)$ scrubber (condensed $\mathrm{HCl}$ on the wall of $20 \mathrm{~cm}$ PFA tubing) where $\mathrm{HOCl}$ is titrated to form $\mathrm{Cl}_{2}$. The increase in $\mathrm{Cl}_{2}$ concentration when the flow is sent through the scrubber is equal to the loss of $\mathrm{HOCl}$ signal and as the calibration factor for $\mathrm{Cl}_{2}$ is known, the relative calibration factor for $\mathrm{HOCl}$ to $\mathrm{Cl}_{2}$ is found.

Additionally, several atmospherically relevant ClVOCs were sampled in the laboratory to assess their detectability by the ToF-CIMS with $\mathrm{I}^{-}$. The instrument was able to detect dichloromethane (DCM, VWR), chloroform $\left(\mathrm{CHCl}_{3}\right.$, $99.8 \%$, Aldrich) and methyl chloride $\left(\mathrm{CH}_{3} \mathrm{Cl}\right.$, synthesised), although the instrument response was poor. The response to 3 -chloropropionic acid was orders of magnitude greater than for the ClVOCs suggesting that the role of the chlorine atom is negligible compared with the carboxylic acid group in determining the $\mathrm{I}^{-}$sensitivity in this case.

\subsection{Cl radical budget calculations}

Within this system, we designate $\mathrm{ClNO}_{2}, \mathrm{HOCl}$ and organic chlorine as sources of $\mathrm{Cl}$. As $\mathrm{HCl}$ was not detected, it is not possible to quantify the contribution of $\mathrm{Cl}$ from the reaction of $\mathrm{HCl}+\mathrm{OH}$. Loss processes of $\mathrm{Cl}$ are $\mathrm{Cl}+\mathrm{O}_{3}$ and $\mathrm{Cl}+\mathrm{CH}_{4}$ (7). Photolysis rates for the $\mathrm{Cl}$ sources are taken from the US National Center for Atmospheric Research 
(NCAR) Tropospheric Ultraviolet and Visible TUV radiation model (Mandronich, 1987) assuming a $100 \%$ quantum yield at our latitude and longitude with a column overhead $\mathrm{O}_{3}$ measured by the Brewer spectrophotometer \#172 (Smedley et al., 2012) and assuming zero optical depth. To account for the effective optical depth of the atmosphere, including clouds and other optical components, we scale our idealised photolysis rate coefficient $(J)$ by the observed transmittance values in the UV-A waveband (325 to $400 \mathrm{~nm}$ ). These transmittance values are calculated from UV spectral scans of global irradiance, measured at half-hourly intervals by the Brewer spectrophotometer and provided as an output of the SHICrivm analysis routine (Slaper et al., 1995). The $\mathrm{Cl}$ rate coefficient for the reaction with $\mathrm{O}_{3}$ is $k_{\mathrm{Cl}+\mathrm{O}_{3}}=1.20 \times$ $10^{-11} \mathrm{~cm}^{3}$ molecule ${ }^{-1} \mathrm{~s}^{-1}$ (Atkinson et al., 2006b) and $\mathrm{CH}_{4}$ is $k_{\mathrm{Cl}+\mathrm{CH}_{4}}=1.03 \times 10^{-13} \mathrm{~cm}^{3}$ molecule ${ }^{-1} \mathrm{~s}^{-1}$ (Atkinson et al., 2006a). The individual $k_{\mathrm{Cl}+\mathrm{VOC}}$ are taken from the NIST chemical kinetics database. This is represented by the following equation;

$$
\begin{gathered}
{[\mathrm{Cl}]_{\mathrm{SS}}=} \\
\frac{J_{\mathrm{HOCl}}[\mathrm{HOCl}]+J_{\mathrm{ClOVOC}} \Sigma[\mathrm{ClVOCs}]}{\mathrm{J}_{\mathrm{Cl}_{2}}\left[\mathrm{Cl}_{2}\right]+J_{\mathrm{ClNO}_{2}}\left[\mathrm{ClNO}_{2}\right]+} \\
k_{\mathrm{O}_{3}+\mathrm{Cl}}\left[\mathrm{O}_{3}\right]+k_{\mathrm{CH}_{4}+\mathrm{Cl}}\left[\mathrm{CH}_{4}\right]+\sum_{i}^{n} k_{\mathrm{Cl}+\mathrm{VOC}_{i}}[\mathrm{VOC}] i .
\end{gathered}
$$

As methane was not measured, an average concentration was taken from the European Centre for Medium-Range Weather Forecasts (ECMWF) Copernicus atmosphere monitoring service (CAMS). VOC concentrations were approximated by applying representative VOC : benzene ratios for the UK urban environment (Derwent et al., 2000) and applying those to a typical urban UK benzene : CO ratio (Derwent et al., 1995), where CO was measured at the Whitworth observatory. The VOC: benzene ratios are scaled to the year of this study to best approximate ambient levels (Derwent et al., 2014). The calculated benzene: $\mathrm{CO}$ ratio is in good agreement with a Non-Automatic Hydrocarbon Network monitoring site (Manchester Piccadilly) approximately $1.5 \mathrm{~km}$ from the measurement location, indicating that the approximation made here is reasonably accurate. The ratios assume that traffic emissions are the dominant source of the VOCs, as is assumed here.

The photosensitivity of the ClOVOCs to wavelengths longer than $280 \mathrm{~nm}$ dictates their ability to contribute to the $\mathrm{Cl}$ budget in the troposphere. As many of the identified species here do not have known photolysis rates, we approximate the photolysis of methyl hypochlorite $J_{\mathrm{CH}_{3} \mathrm{OCl}}$ for all ClOVOCs, as it is the only available photolysis rate for an oxygenated organic compound containing a chlorine atom provided by the TUV model and no other more suitable photolysis rate could be found elsewhere, e.g. the JPL kinetics database. The same quantum yield and actinic flux assumptions are made.

\section{Results}

Concentrations of all chlorinated species are higher at the beginning of the measurement campaign, when air masses originating from continental Europe were sampled (ReyesVillegas et al., 2018). Toward the end of the measurement campaign, $\mathrm{ClNO}_{2}$ and $\mathrm{ClOVOCs}$ concentrations were low, which is consistent with the pollution during this period having a high fraction of primary components (Reyes-Villegas et al., 2018), see Fig. 1.

\subsection{Inorganic chlorine}

We detect a range of inorganic chlorine species and frag-

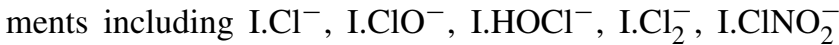
and $\mathrm{I} \mathrm{ClONO}_{2}^{-}$, however we do not detect $\mathrm{I}^{-\mathrm{ClO}_{2}^{-}}, \mathrm{I}^{-\mathrm{Cl}_{2} \mathrm{O}^{-}}$, I. $\mathrm{Cl}_{2} \mathrm{O}_{2}^{-}$, I.ClNO${ }^{-}$or I. $\mathrm{HCl}^{-}$. Laboratory studies have shown that the ToF-CIMS is sensitive to detection of $\mathrm{I}^{-\mathrm{HCl}^{-}}$, however under this configuration, the $\mathrm{I}_{\mathrm{HCl}} \mathrm{HC}^{-}$adduct was not observed. The statistics of the concentrations reported below do not take into account the limits of detection (LOD), so for some of the measurements, values may be reported below the LOD.

\subsection{1 $\mathrm{ClNO}_{2}$}

$\mathrm{ClNO}_{2}(m / z$ 208) was detected every night of the campaign with an LOD ( $3 \times$ standard deviation of the background $)$ of $3.8 \mathrm{ppt}$. The $1 \mathrm{~Hz}$ mean night-time concentration of $\mathrm{ClNO}_{2}$ was $58 \mathrm{ppt}$ (not accounting for the LOD), and a maximum of $506 \mathrm{ppt}$ (not accounting for the LOD) was measured as a large spike on the evening of 30 October. These concentrations are comparable to other urban UK measured values, although the maximum concentration reported here is $30 \%$ lower than that measured in London (Bannan et al., 2015) but is consistent with high concentrations expected during the winter, as discussed in the introduction.

The diurnal profile of $\mathrm{ClNO}_{2}$ increases through the evening to a local morning maximum, with rapid loss after sunrise. Although we observe a rapid build-up after sunset (ca. 16:30 LT) and loss after sunrise (ca. 07:30 LT), the maximum concentration measured within a given $24 \mathrm{~h}$ period typically peaks at around 22:00 LT and halves by 03:00 LT, where it is maintained. The reasons for the early onset in peak concentration and loss throughout the night is unclear, although on 1 November, a sharp decrease in $\mathrm{ClNO}_{2}$ is a consequence of a change in wind direction, indicating that the source of $\mathrm{ClNO}_{2}$ is directional. A minimum concentration of $\angle \mathrm{LOD}$ is reached by 15:00 LT, indicating that concentrations can persist for much of the day. On 7 November $\mathrm{ClNO}_{2}$ concentrations grow throughout the morning, even after photolysis begins, until 11:00 LT. Correlated high wind speeds suggest that the long-range transport and downward mixing is a likely cause for this daytime increase. 

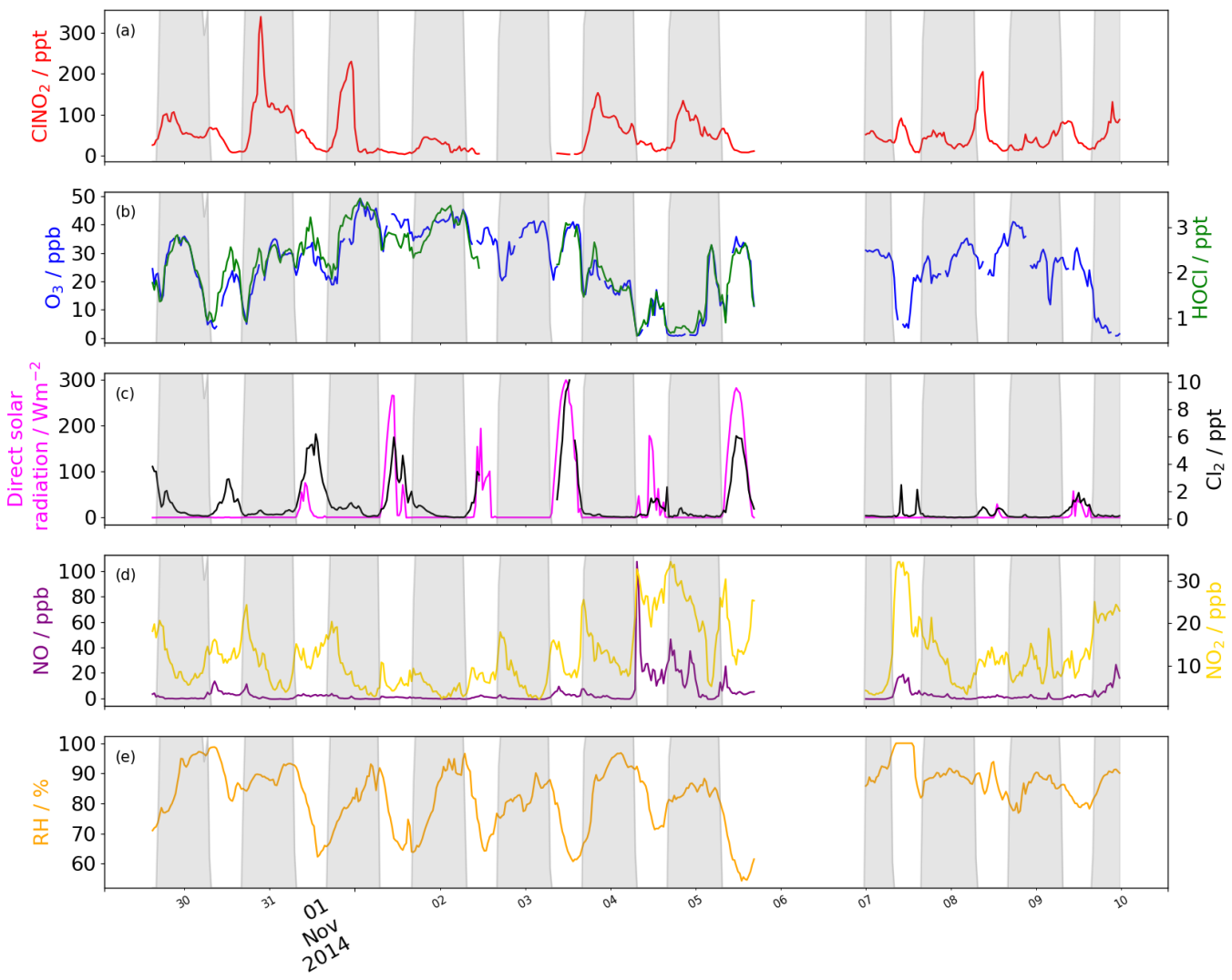

Figure 1. Time series of (a) $\mathrm{ClNO}_{2}(\mathrm{ppt})$, (b) $\mathrm{HOCl}(\mathrm{ppt})$ and $\mathrm{O}_{3}(\mathrm{ppb})$, and (c) $\mathrm{Cl}_{2}$ (ppt) and direct solar radiation (Wm ${ }^{-2}$ ). (d) $\mathrm{NO}(\mathrm{ppb})$ and $\mathrm{NO}_{2}(\mathrm{ppb})$. (e) Relative humidity (\%). Data is removed during bonfire night (5-6) and $\mathrm{HOCl}$ data is discounted thereafter due to a persistent interference that was not present earlier.

Typically, elevated concentrations of $\mathrm{ClNO}_{2}$ are measured when the wind direction is easterly and wind speeds are low $\left(2-4 \mathrm{~ms}^{-1}\right)$, also during periods of southerly winds between $3-9 \mathrm{~ms}^{-1}$. The potential sources of $\mathrm{Cl}^{-}$precursor from these directions are industrial sites, including waste water treatment facilities $(8.5 \mathrm{~km}$ east and $7.0 \mathrm{~km}$ south) that may use salt water as part of the chemical disinfection process (Ghernaout and Ghernaout, 2010). Another source of the $\mathrm{ClNO}_{2}$ precursor is found from the southwest at wind speeds of $9 \mathrm{~ms}^{-1}$, indicating a more distant source that is also likely to be industrial or marine. The correlation between $\mathrm{ClNO}_{2}$ and $\mathrm{Cl}_{2}$ is poor at most times, apart from the night of the 30 where a strong linear relationship is observed. This is consistent with polluted continental air masses advecting a variety of trace gases. Throughout the measurement campaign the relationship between $\mathrm{ClNO}_{2}$ and $\mathrm{Cl}_{2}$ is poor, so it is unlikely they share the same source.

\subsubsection{HOCl}

$\mathrm{HOCl}$ concentrations average $2.18 \mathrm{ppt}$ (not accounting for the LOD) and reach a daytime maximum of $9.28 \mathrm{ppt}$ with an LOD of 3.8 ppt. Concentrations peak in the early afternoon, similarly to $\mathrm{Cl}_{2}$, but remain elevated for longer, dropping after sunset. The diurnal profile is similar to that for $\mathrm{O}_{3}$, with a maximum during the day and minima during morning and evening rush hours when $\mathrm{NO}_{x}$ is emitted locally. The strong correlation with $\mathrm{O}_{3}\left(R^{2}=0.67\right)$ is expected, as the route to the formation of $\mathrm{HOCl}$ is the oxidation of $\mathrm{Cl}$ with $\mathrm{O}_{3}$ to form $\mathrm{ClO}$ and then the oxidation by $\mathrm{HO}_{2}$ to form HOCl. Nonnegligible night-time concentrations of a maximum $8.1 \mathrm{ppt}$ are only measured when concentrations of other inorganic $\mathrm{Cl}$ containing species are high. The HOCl signal is artificially elevated after the night of the 5 due to a persistent interference from a large-scale biomass burning event (Guy Fawkes Night, Priestley et al., 2018), which cannot be de-convolved from the dataset due to the small difference in their massto-charge ratios and insufficient instrument resolution. For this reason $\mathrm{HOCl}$ data after this date are discounted from the analysis.

\subsubsection{ClO}

We detect the $\mathrm{I}^{-\mathrm{ClO}^{-}}$adduct at $m / z .178$, which strongly correlates with $\mathrm{I} . \mathrm{ClNO}_{2}^{-}$and $\mathrm{I}^{-\mathrm{Cl}^{-}}$signals, all of which show night-time maxima. This is inconsistent with the $\mathrm{ClO}$ photo- 
chemical production pathway of $\mathrm{Cl}+\mathrm{O}_{3}$, suggesting that its maximum concentration should be measured during the day, as was observed for $\mathrm{HOCl}$. It is not possible to confirm if the $\mathrm{I} \mathrm{ClO}^{-}$is a fragment of a larger $\mathrm{ClO}$ containing molecule, however, as the fragmentation of multiple larger molecules are detected as a single adduct, e.g. the $\mathrm{I}^{-\mathrm{Cl}^{-}}$cluster is a known fragment from $\mathrm{ClNO}_{2}$ and $\mathrm{HOCl}$, it is reasonable to suspect that $\mathrm{I} \mathrm{ClO}^{-}$may be a fragment as well.

\subsection{4 $\mathrm{Cl}_{2}$}

We observe concentrations of $\mathrm{Cl}_{2}$ during the day ranging from $0-16.6 \mathrm{ppt}$ with a mean value of $2.3 \mathrm{ppt}$ (not accounting for the LOD) and night-time concentrations of $0-4.7 \mathrm{ppt}$ with mean concentrations of $0.4 \mathrm{ppt}$ (not accounting for the LOD), see Fig. 1. The LOD is $0.5 \mathrm{ppt}$ and a calibration factor of $4.5 \mathrm{~Hz} \mathrm{ppt}^{-1}$ was found. These concentrations are of the same order of magnitude as measured at an urban site in the US but up to 2 orders of magnitude smaller than at US urban costal sites (Keene et al., 1993; Spicer et al., 1998) and a megacity impacted rural site in northern China (Liu et al., 2017). Although the maximum measured value here is an order of magnitude greater than that measured in Houston (Faxon et al., 2015), the photolysis rate of $\mathrm{Cl}_{2}$ here is 2 orders of magnitude smaller compared with Houston at that time.

The diurnal profile of $\mathrm{Cl}_{2}$ exhibits a maximum at midday and minimum at night (early morning) consistent with other studies (Faxon et al., 2015; Liao et al., 2014; Liu et al., 2017). The days with the greatest concentration are those where direct shortwave radiation is at its highest. On 5 November, the incidence of direct shortwave radiation is unhindered throughout the day and a similarly uniform profile for $\mathrm{Cl}_{2}$ is also observed. On 1 November, $\mathrm{Cl}_{2}$ concentrations increase unhindered as direct radiation increases but when cloud cover reduces radiation transmission efficiency, a corresponding drop in $\mathrm{Cl}_{2}$ is also observed (Fig. 2). Also, when global radiation is low throughout the day, e.g. 7 November, we observe very low concentrations of $\mathrm{Cl}_{2}$.

There is the potential that the $\mathrm{Cl}_{2}$ signal detected is an instrumental artefact generated either by chemistry in the IMR or from displacement reactions or degassing on the inlet walls. We believe none of these to be the case. First, the correlation between the signal used for labile chlorine in the IMR ${ }^{35} \mathrm{Cl}\left(\mathrm{m} / z\right.$ 35) is high with $\mathrm{ClNO}_{2}\left(R^{2}=0.98\right)$ yet is non-existent with $\mathrm{Cl}_{2}\left(R^{2}=0.01\right)$ indicating $\mathrm{Cl}_{2}$ concentration is independent of ${ }^{35} \mathrm{Cl}$ concentrations. Second, there is no correlation between $\mathrm{HNO}_{3}$ and $\mathrm{Cl}_{2}\left(R^{2}=0.07\right)$ which suggests that acid displacement reactions are not occurring on the inlet walls. Third, there is no correlation between temperature and $\mathrm{Cl}_{2}\left(R^{2}=0.08\right)$, indicating that localised ambient inlet heating is also not a contributing factor to increased $\mathrm{Cl}_{2}$ concentrations. Fourth, we observe a similar direct radiation dependency for other photochemical species as we observe for $\mathrm{Cl}_{2}$. For example, the temporal behaviour of
$\mathrm{C}_{2} \mathrm{H}_{4} \mathrm{O}_{5}$ exhibits a similar diurnal profile and radiation dependency (Fig. 2). Also, the production of $\mathrm{O}_{3}$ increases and decreases with direct solar radiation at the same times we observe the enhancements in concentrations of $\mathrm{Cl}_{2}$ and $\mathrm{C}_{2} \mathrm{H}_{4} \mathrm{O}_{5}$ (Fig. 2). The changes in $\mathrm{O}_{3}$ production are observed when $\mathrm{NO}$ concentrations are near zero, indicating that $\mathrm{O}_{3}$ production is VOC limited. Finally, other large organic molecules e.g. $\mathrm{C}_{10} \mathrm{H}_{14} \mathrm{O}_{4}$ do not exhibit this strong coupling with direct solar radiation. This evidence suggests that a local photolytic daytime mechanism is responsible for the increase in daytime concentrations as has previously been suggested (e.g. Finley and Saltzman, 2006).

Although peak concentrations of $\mathrm{Cl}_{2}$ are observed in the daytime, high levels of $\mathrm{Cl}_{2}$ are also observed during the night. At the beginning of the measurement period, which has previously been characterised using an aerosol mass spectrometer (AMS) as a period of high secondary activity (Reyes-Villegas et al., 2018), there are persistent, non-zero concentrations of $\mathrm{Cl}_{2}(\leq 4 \mathrm{ppt})$ after sunset. On 4 November, after the period of high secondary activity, intermittent elevations in night-time $\mathrm{Cl}_{2}$ concentrations when the wind is northerly suggest that a local emission source, with concentrations reaching a maximum of $4.6 \mathrm{ppt}$. Two more distinct night-time sources, ranging from the south west through to the east of the measurement site, indicate a likely origin in industrial areas, some of which contain chemical production and water treatment facilities.

\subsection{Organic chlorine}

We detected seven $\mathrm{C}_{2}-\mathrm{C}_{6}$ ClOVOCs of the forms $\mathrm{C}_{n} \mathrm{H}_{2 n+1} \mathrm{O}_{1} \mathrm{Cl}, \quad \mathrm{C}_{n} \mathrm{H}_{2 n+1} \mathrm{O}_{2} \mathrm{Cl}, \quad \mathrm{C}_{n} \mathrm{H}_{2 n+1} \mathrm{O}_{3} \mathrm{Cl}$, $\mathrm{C}_{n} \mathrm{H}_{2 n-1} \mathrm{O}_{2} \mathrm{Cl}, \mathrm{C}_{n} \mathrm{H}_{2 n-1} \mathrm{O}_{3} \mathrm{Cl}$ and $\mathrm{C}_{n} \mathrm{H}_{2 n-3} \mathrm{O}_{2} \mathrm{Cl}$ (Fig. 3), of which only $\mathrm{C}_{2} \mathrm{H}_{3} \mathrm{O}_{2} \mathrm{Cl}$ has been previously reported (Le Breton et al., 2018). We find no evidence for the detection of small chlorohydrocarbons, e.g. poly-chloromethanes, such as methyl chloride, dimethyl chloride and chloroform, or poly-chloroethanes such as those described by Huang et al. (2014) in the ambient data, but qualitative testing and laboratory calibrations show that the iodide reagent ion can detect $\mathrm{CH}_{3} \mathrm{Cl}$ (not calibrated), $\mathrm{CH}_{2} \mathrm{Cl}_{2} \quad(\mathrm{LOD}=143 \mathrm{ppb})$ and $\mathrm{CHCl}_{3}$ (LOD=11 ppb). We find no discernible evidence for the detection of 4-chlorocrotonaldehyde, the $\mathrm{Cl}$ oxidation product of 1,3-butadiene and unique marker of chlorine chemistry (Wang and Finlayson-Pitts, 2001) due to interferences from other $\mathrm{CHO}$ compounds. We do not believe that these species are products of inlet reactions as there is a poor correlation $\left(R^{2}=-0.039\right)$ with labile chlorine ${ }^{35} \mathrm{Cl}$.

The maximum hourly averaged total ClOVOCs concentration is $28 \mathrm{ppt}$ at $12: 00 \mathrm{LT}$ and at a minimum of 5 ppt at 07:00 LT, when $\mathrm{NO}_{x}$ concentrations are highest at $\sim 30 \mathrm{ppb}$. Concentrations of $\mathrm{C}_{2} \mathrm{H}_{3} \mathrm{O}_{2} \mathrm{Cl}$ (tentatively identified as chloroacetic acid) and $\mathrm{C}_{6} \mathrm{H}_{13} \mathrm{OCl}$ (tentatively identified as chloro-hexanol) are the highest of any ClOVOCs, ac- 

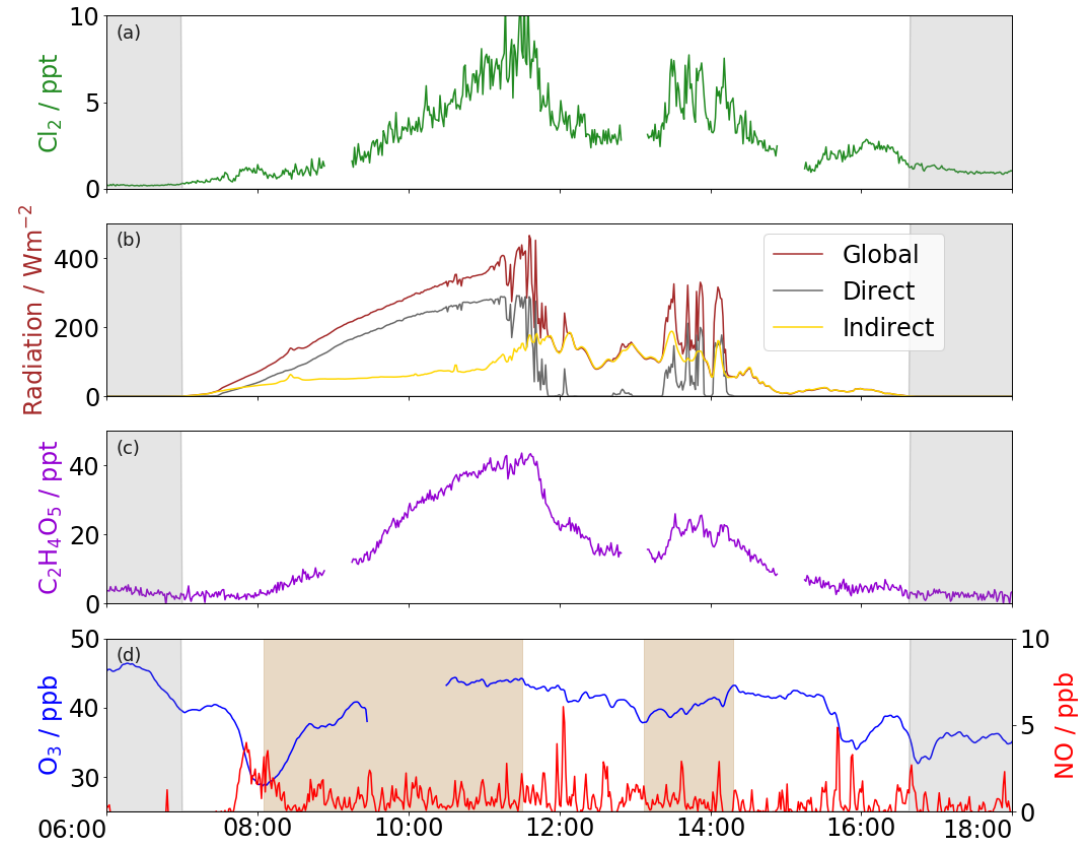

Figure 2. Time series for 1 November 2014, with (a) $\mathrm{Cl}_{2}$, (b) solar radiation (global, direct and indirect), (c) photochemical marker $\mathrm{C}_{2} \mathrm{H}_{4} \mathrm{O}_{5}$, and (d) $\mathrm{O}_{3}$ and $\mathrm{NO}_{x}$, where highlighted boxes demonstrate that $\frac{\Delta\left[\mathrm{O}_{3}\right]}{\Delta t}$ is increasing. The increase in concentration of $\mathrm{Cl}_{2}, \mathrm{C}_{2} \mathrm{H}_{4} \mathrm{O}_{5}$ and $\mathrm{O}_{3}$ production when VOC limited are strongly coupled with direct solar radiation. Greyed areas are night time.
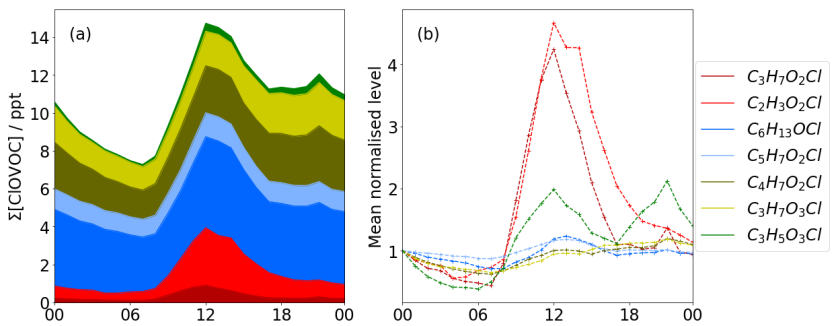

Figure 3. Diurnal profiles of Cl VOCs. (a) Stacked plot showing total $\mathrm{Cl}$ VOC concentration. (b) The first data point of each diurnal trace is mean normalised to 1.0. Reds show photochemical dominated signals with maxima at midday, whereas yellow and blue traces show a more typical diurnal concentration profile associated with changes in boundary layer height, indicating that these species have longer lifetimes.

counting for between $20 \%$ and $30 \%$ of total ClOVOCs concentrations measured. All concentrations rise towards midday, with $\mathrm{C}_{3} \mathrm{H}_{7} \mathrm{O}_{2} \mathrm{Cl}$ and $\mathrm{C}_{2} \mathrm{H}_{3} \mathrm{O}_{2} \mathrm{Cl}$ rising the most by a factor of 4 and returning to nominal levels by the early evening (red in Fig. 3). $\mathrm{C}_{3} \mathrm{H}_{7} \mathrm{O}_{2} \mathrm{Cl}$ and $\mathrm{C}_{2} \mathrm{H}_{3} \mathrm{O}_{2} \mathrm{Cl}$ correlate well with $\mathrm{Cl}_{2}\left(R^{2} 0.77\right.$ and 0.75 , respectively), which is consistent with a photochemical formation mechanism identifying these species as secondary products, potentially chloropropanediol and chloro-acetic acid.

Whilst the diurnal profiles of $\mathrm{C}_{6} \mathrm{H}_{13} \mathrm{OCl}$ and $\mathrm{C}_{5} \mathrm{H}_{7} \mathrm{O}_{2} \mathrm{Cl}$ (blue in Fig. 3) are similar to those of $\mathrm{C}_{3} \mathrm{H}_{7} \mathrm{O}_{2} \mathrm{Cl}$ and
$\mathrm{C}_{2} \mathrm{H}_{3} \mathrm{O}_{2} \mathrm{Cl}$, they do not enhance as much as those photochemical species or return to nominal levels after the solar maximum. Instead, they increase again during the night, with $\mathrm{C}_{3} \mathrm{H}_{5} \mathrm{O}_{3} \mathrm{Cl}$ reaching a maximum concentration of $8 \mathrm{ppt}$ at 20:00 LT. This trend suggests that concentration changes could be a function of boundary layer height.

$\mathrm{C}_{3} \mathrm{H}_{7} \mathrm{O}_{2} \mathrm{Cl}$ and $\mathrm{C}_{4} \mathrm{H}_{7} \mathrm{O}_{2} \mathrm{Cl}$ (yellow in Fig. 3) are the only ClOVOCs that show a positive correlation with $\mathrm{NO}_{x}$ $\left(R^{2}=0.42, R^{2}=0.41\right)$ and negative correlation with $\mathrm{O}_{3}$ $\left(R^{2}=-0.58, R^{2}=-0.53\right)$. Their correlation is stronger with $\mathrm{NO}_{2}\left(R^{2}=0.55, R^{2}=0.48\right)$, a product of traffic emission. This suggests that at least some of the time, they accumulate at low wind speeds, indicating their origins as local, primary emissions or as thermal degradation products that have a traffic source, e.g. polychlorinated dibenzo- $p$-dioxins/dibenzofurans (PCDD/F) and their oxidation products (Fuentes et al., 2007; Heeb et al., 2013). The diurnal profile shows maxima during midday consistent with other photochemical species, which is expected of secondary formation. It is possible that these compounds are isobaric or isomeric with the other compounds that interfere with the perceived signals recorded here.

The diurnal profile of $\mathrm{C}_{3} \mathrm{H}_{5} \mathrm{O}_{3} \mathrm{Cl}$ (green in Fig. 3) exhibits a similar shape to the bimodal distribution observed for $\mathrm{NO}_{x}$. Cross-correlation indicates that a time lag of $-3 \mathrm{~h}$ provides the best correlation with $\mathrm{NO}_{2}$ of $R^{2}=0.80$. This suggests that local oxidation chemistry, which takes place over long 

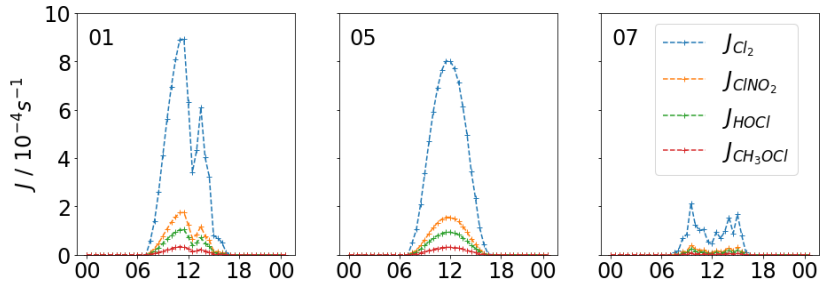

Figure 4. Transmission scaled $J$ values for $\mathrm{Cl}_{2}, \mathrm{ClNO}_{2}$ and $\mathrm{HOCl}$ for 1, 5 and 7 November, where 1 November had high photolysis rates in the morning that were reduced during the afternoon, 5 November is the closest to a full day's ideal photolysis and 7 November shows very weak photolysis.

periods in the day and is sensitive to traffic emission, is the source of this ClOVOC.

\section{Discussion}

\subsection{Effect of global radiation transmission efficiency on $\mathrm{Cl}$ radical production}

Three days are selected based on their different solar short wave transmission efficiencies to quantify the variation in $\mathrm{Cl}_{2}$ formation and photolysis and thus the influence of $\mathrm{Cl}_{2}$ on producing $\mathrm{Cl}$. The average transmission of global radiation on 5 November was high with $84 \pm 14 \%(1 \sigma)$, whereas on 7 November it was very low with $21 \pm 14 \%$, sometimes dropping below $10 \%$ in the middle of the day. The middle case is represented by 1 November, where the transmission efficiency in the morning was high with $88 \pm 11 \%$, but in the afternoon it was highly variable and dropped to $55 \pm 20 \%$ (see Fig. 4). These 3 days provide good case studies for the investigation of the effect of global radiation on molecular chlorine concentrations and therefore the production of $\mathrm{Cl}$.

The reduced transmission efficiency inhibits $\mathrm{Cl}_{2}$ formation, thereby reducing the contribution of $\mathrm{Cl}_{2}$ to $\mathrm{Cl}$ production. The lower transmission efficiency also reduces the photolysis of $\mathrm{Cl}_{2}$ and so reduces the production of $\mathrm{Cl}$ even further. Figure 5 shows the divergence between the ideal $J_{\mathrm{Cl}_{2}}$ without transmission efficiency correction (a), the $J_{\mathrm{Cl}_{2}}$ value scaled by transmission efficiency (b) and subsequent $\mathrm{Cl}$ formation. $\mathrm{Cl}$ production rates are similar until 11:00 LT, when the scaled production then becomes an average $47 \%$ lower. This is most prominent at 13:00 LT, when the difference between ideal and scaled production is $8.4 \times 10^{4} \mathrm{Cl}$ radicals $\mathrm{cm}^{-3} \mathrm{~s}^{-1}$.

\subsection{Contribution of inorganic chlorine to $\mathrm{Cl}$ radical production}

The contribution of $\mathrm{HOCl}$ and ClOVOCs to $\mathrm{Cl}$ formation is negligible due to low photolysis rates and low concentrations, whereas the contributions from $\mathrm{Cl}_{2}$ and

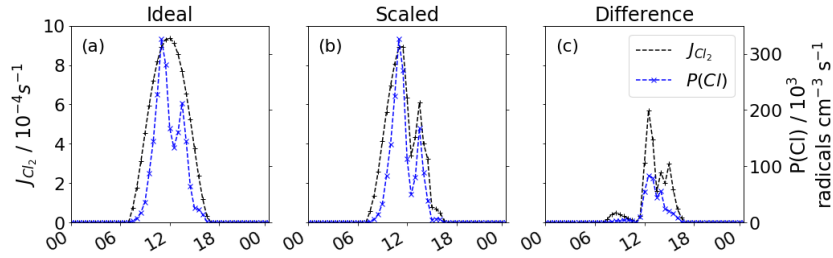

Figure 5. Diurnal profile for 1 November of (a) idealised $J_{\mathrm{Cl}_{2}}$ and $P(\mathrm{Cl})$, (b) scaled $J_{\mathrm{Cl}_{2}}$ and $P(\mathrm{Cl})$, and (c) the difference between (a) and (b). Transmission efficiency scaled photolysis reduce $P(\mathrm{Cl})$ from $\mathrm{Cl}_{2}$ photolysis.

$\mathrm{ClNO}_{2}$ are much greater (Fig. 6). During the morning of 5 November, $\mathrm{ClNO}_{2}$ is the dominant source of $\mathrm{Cl}$, contributing $95 \%$ of the total $\mathrm{Cl}$ concentration, a maximum of $3.0 \times 10^{3} \mathrm{Cl}$ radicals $\mathrm{cm}^{-3}$, to the steady-state concentration, which is approximately a factor of 3 lower than the estimated maximum concentration of $9.5 \times 10^{3} \mathrm{Cl}$ radicals $\mathrm{cm}^{3}$ produced by $\mathrm{ClNO}_{2}$ photolysis in London during the summer (Bannan et al., 2015) and a factor of 22 lower than the maximum concentration of $85.0 \times 10^{3} \mathrm{Cl}$ radicals $\mathrm{cm}^{-3} \mathrm{cal}-$ culated from measurements of $\mathrm{ClNO}_{2}$ in Houston (Faxon et al., 2015). In both instances, this is due to a combination of lower $J_{\mathrm{ClNO}_{2}}$ and lower $\mathrm{ClNO}_{2}$ concentrations.

As the day progresses, concentrations of $\mathrm{Cl}_{2}$ increase and it becomes the dominant and more sustained source of $\mathrm{Cl}$ by contributing $95 \%$ of $\mathrm{Cl}\left(12.5 \times 10^{3} \mathrm{Cl}\right.$ radicals cm $\left.\mathrm{cm}^{-3}\right)$ by the early afternoon, which is approximately $4 \times$ that of the $\mathrm{ClNO}_{2}$ measured in the early morning and $1.3 \times$ higher than the maximum estimated concentration calculated from the $\mathrm{ClNO}_{2}$ photolysis in London (Bannan et al., 2015). The maximum $\mathrm{Cl}$ concentration produced from $\mathrm{Cl}_{2}$ and $\mathrm{ClNO}_{2}$ photolysis on 5 November reached $14.2 \times 10^{3} \mathrm{Cl}_{\text {radicals }} \mathrm{cm}^{3}$ at 11:30 LT which is approximately $16 \%$ of the $85.0 \times$ $10^{3} \mathrm{Cl}$,radicals $\mathrm{cm}^{3}$ maximum calculated value from the photolysis of these two species in Houston in summer (Faxon et al., 2015). This is dominated by the contribution of $\mathrm{Cl}_{2}$, indicating that $\mathrm{Cl}_{2}$ can be a much more significant source of $\mathrm{Cl}$ than $\mathrm{ClNO}_{2}$. On this high-flux day, when hourly mean $\mathrm{Cl}_{2}$ concentrations range between $0-7 \mathrm{ppt}$, the source term is calculated between 4-21 ppt $\mathrm{Cl}_{2} \mathrm{~h}^{-1}$, which is slightly lower, although consistent with previous studies (Faxon et al., 2015; Finley and Saltzman, 2006; Spicer et al., 1998).

A day with low photolysis rates and high daytime $\mathrm{ClNO}_{2}$ concentrations has been highlighted as 7 November. On this day, $\mathrm{ClNO}_{2}$ is the dominant $\mathrm{Cl}$ source $(95 \%)$ reaching a maximum of $3.4 \times 10^{3} \mathrm{Cl}$ radicals $\mathrm{cm}^{-3}$ at 09:30 LT, which is $\sim 87 \%$ of that calculated for London (Bannan et al., 2015). A mean $\mathrm{Cl}_{2}$ concentration of $0.3 \mathrm{ppt}$ (less than the LOD of $0.5 \mathrm{ppt}$ ) on this day is very low, as production of $\mathrm{Cl}_{2}$ at its maximum, calculated as $0.6 \mathrm{ppth}^{-1}$, is also low. This combined with a low maximum of $J_{\mathrm{Cl}_{2}}=1.13 \times 10^{-4} \mathrm{~h}^{-1}$ means that maximum $\mathrm{Cl}$ production from $\mathrm{Cl}_{2}$ photolysis on this day is very low, generating $0.9 \times 10^{3} \mathrm{Cl}$ radicals $\mathrm{cm}^{-3}$ at 10:00 LT 


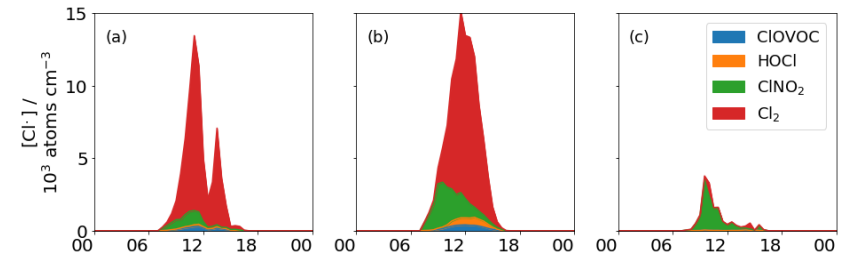

Figure 6. Steady state concentration of $\mathrm{Cl}$ from $\mathrm{ClNO}_{2}, \mathrm{Cl}_{2}, \mathrm{HOCl}$ and total ClOVOC photolysis for (a) 1 November, (b) 5 November, and (c) 7 November. The importance of $\mathrm{ClNO}_{2}$ during the morning is most evident on the 5, with a diminishing contribution throughout the day. On the high-flux days, $\mathrm{Cl}_{2}$ is the most important source of $\mathrm{Cl}$, but on the low-flux day, $\mathrm{ClNO}_{2}$ is most important.

or a quarter of the maximum contributed by $\mathrm{ClNO}_{2}$ on this day (see Fig. 6). This is represented by the following equation;

$\mathrm{Cl}_{(\mathrm{aq})}^{-} \stackrel{J}{\longrightarrow} \frac{1}{2} \mathrm{Cl}_{2(g)} \stackrel{J_{\mathrm{Cl}_{2}}}{\longrightarrow} \mathrm{Cl}$.

The dependency of $\mathrm{Cl}$ formation on $\mathrm{Cl}_{2}$ production and loss highlights the sensitivity of this reaction channel to the photolysis that is demonstrated on these 2 days. The production of $\mathrm{Cl}$ from $\mathrm{ClNO}_{2}$ is less sensitive, relatively speaking, to the solar flux, as the production of $\mathrm{ClNO}_{2}$ does not rely on photochemistry but chemical composition cf. Eqs. (6) and (8). This further highlights the role of photolytic mechanisms in the re-activation of particulate chloride to gaseous chlorine radicals.

\subsection{Organic vs. inorganic contribution to $\mathrm{Cl}$ radical production}

Summing the concentrations of the ClOVOCs and assuming a uniform photolysis rate $J_{\mathrm{CH}_{3} \mathrm{OCl}}$ as detailed in the above section, we derive the contribution of total measured $\mathrm{ClOVOC}$ to the $\mathrm{Cl}$ budget and compare it to the contribution from inorganic $\mathrm{Cl}$ measured here (Fig. 6). On the high-flux day, the $\mathrm{Cl}$ concentration reaches $4.0 \times 10^{2} \mathrm{Cl}_{\text {radicals }} \mathrm{cm}^{-3}$ at midday, which is $30 \%$ of the contribution by $\mathrm{ClNO}_{2}, 3.6 \%$ of the contribution from $\mathrm{Cl}_{2}$ and $2 \%$ of the $\mathrm{HOCl}$ contribution for the same day. On the low-flux day, the ClOVOC contribution is $11.0 \times 10^{2} \mathrm{Cl}$ radicals $\mathrm{cm}^{-3}$, which is $\sim 2.8 \%$ of the $\mathrm{ClNO}_{2}$ contribution on that day and $\sim 57 \%$ of the $\mathrm{Cl}_{2}$ contribution. Like $\mathrm{Cl}_{2}$, the production of most ClOVOC requires a photolytic step to generate concentrations that can then go on to decompose, providing the $\mathrm{Cl}$. Here it is suggested that the organic contribution to $\mathrm{Cl}$ production is negligible at $15 \%$ on the low radiant-flux day and $3 \%$ on the high-flux day.

\section{Conclusions}

A large suite of inorganic and organic, oxygenated, chlorinated compounds has been identified in ambient, urban air during the wintertime in the UK. Of the seven organic chlorinated compounds (ClOVOCs) identified here, only $\mathrm{C}_{2} \mathrm{H}_{3} \mathrm{O}_{2} \mathrm{ClO}$ (tentatively assigned as chloroacetic acid) has previously been reported. Although the ToF-CIMS with $\mathrm{I}^{-}$ is sensitive towards chlorinated and polychlorinated aliphatic compounds, e.g. methyl chloride $\left(\mathrm{CH}_{3} \mathrm{Cl}\right)$ dimethyl chloride $\left(\mathrm{CH}_{2} \mathrm{Cl}_{2}\right)$ and chloroform $\left(\mathrm{CHCl}_{3}\right)$, their concentrations were below the detection limit. The sources of ClOVOCs are mostly photochemical with maxima of up to $28 \mathrm{ppt}$ observed at midday, although $\mathrm{C}_{3} \mathrm{H}_{7} \mathrm{O}_{3} \mathrm{Cl}$ and $\mathrm{C}_{4} \mathrm{H}_{7} \mathrm{O}_{2} \mathrm{Cl}$ concentrations correlate with $\mathrm{NO}_{x}$ accumulating at low wind speeds, indicating they are produced locally, potentially as the thermal breakdown products of higher-mass chlorinated species such as polychlorinated dibenzo- $-p$-dioxins/dibenzofurans (PCDD/F) from car exhausts or the oxidation products thereof. $\mathrm{C}_{3} \mathrm{H}_{5} \mathrm{O}_{3} \mathrm{Cl}$ shows a good diurnal cross-correlation with $\mathrm{NO}_{2}$ with a time lag of $3 \mathrm{~h}$, suggesting that its production is sensitive to $\mathrm{NO}_{x}$ concentrations on that time scale.

Alongside ClOVOCs, daytime concentrations of $\mathrm{Cl}_{2}$ and $\mathrm{ClNO}_{2}$ are measured, reaching maxima of 17 and $506 \mathrm{ppt}$, respectively. $\mathrm{ClNO}_{2}$ is a source of $\mathrm{Cl}$ in every daytime period measured. $\mathrm{Cl}_{2}$ shows strong evidence of a daytime production pathway limited by photolysis as well as emission sources evident during the evening and night time.

On a day of high radiant flux $(84 \pm 14 \%$ of idealised values), $\mathrm{Cl}_{2}$ is the dominant source of $\mathrm{Cl}$, generating a maximum steady state concentration of $12.5 \times$ $10^{3} \mathrm{Cl}$ radicals $\mathrm{cm}^{-3}$ or $74 \%$ of the total $\mathrm{Cl}$ produced by the photolysis of $\mathrm{Cl}_{2}, \mathrm{ClNO}_{2}, \mathrm{HOCl}$ and $\mathrm{ClOVOC}$, with the latter three contributing $19 \%, 4 \%$ and $3 \%$, respectively. This contrasts with a share of $14 \%$ for $\mathrm{Cl}_{2}, 83 \%$ for $\mathrm{ClNO}_{2}$ and $3 \%$ for ClOVOCs on a low radiant-flux day $(21 \pm 14 \%$ of idealised values). On the low radiance day, not only is the photolysis of all $\mathrm{Cl}$ species inhibited, reducing $\mathrm{Cl}$ concentrations, but also the formation of $\mathrm{Cl}_{2}$ and some ClOVOCs by photochemical mechanisms is inhibited, thus the variability in contribution between days is highly sensitive to the incidence of sunlight. This further highlights the importance of photochemistry in the re-activation of particulate chloride to gaseous chlorine radicals. Similarly to $\mathrm{Cl}_{2}, \mathrm{ClOVOCs}$ can be an important source of $\mathrm{Cl}$, although the behaviour of their contribution is similar to $\mathrm{Cl}_{2}$, relying on high rates of photolysis rather than high concentrations as is the case for $\mathrm{ClNO}_{2}$.

The contribution of the ClOVOCs to the $\mathrm{Cl}$ budget would be better determined if more specific photolysis rates for each compound were available and so would further improve the accuracy of the contribution they make to the $\mathrm{Cl}$ budget. In addition, future work should aim to identify the processes leading to the formation of these compounds to better constrain the $\mathrm{Cl}$ budget in the urban atmosphere. Further ambient measurements of a broader suite of chlorinated species as 
shown here in different chemical environments would help to better constrain the contribution that chlorine-initiated chemistry has on a global scale.

Data availability. The data are to be uploaded to http://catalogue. ceda.ac.uk/ (last access: 20 September 2018).

Author contributions. MP, MIB, TJB and AB operated the CIMS during for the measurement period. Data analysis was performed by MP, MIB and TJB. ERV and JA aided with data analysis. The manuscript was written by MP. MP, SDW and AM performed laboratory calibrations. ARDS and AW provided transmittance data and contributed to that section of the manuscript. DES and CJP provided assistance with the steady-state calculation. DES, CJP and HC supported with project management and manuscript refinement.

Competing interests. The authors declare that they have no conflict of interest.

Acknowledgements. This work was conducted during a $\mathrm{PhD}$ study supported by the Natural Environment Research Council (NERC) EAO Doctoral Training Partnership and is fully funded by NERC, whose support is gratefully acknowledged (Grant ref no. NE/L002469/1).

Edited by: Steven Brown

Reviewed by: two anonymous referees

\section{References}

Atkinson, R., Baulch, D., Cox, R., and Crowley, J.: Summary of Evaluated Kinetic and Photochemical Data for Atmospheric Chemistry, Web Version, February 2006, IUPAC Subcomm. Gas Kinet. Data Eval. Atmos. Chem., 1-60, 2006a.

Atkinson, R., Baulch, D. L., Cox, R. A., Crowley, J. N., Hampson, R. F., Hynes, R. G., Jenkin, M. E., Rossi, M. J., Troe, J., and IUPAC Subcommittee: Evaluated kinetic and photochemical data for atmospheric chemistry: Volume II - gas phase reactions of organic species, Atmos. Chem. Phys., 6, 3625-4055, https://doi.org/10.5194/acp-6-3625-2006, 2006b.

Bannan, T. J., Murray Booth, A., Bacak, A., Muller, J. B. A., Leather, K. E., Le Breton, M., Jones, B., Young, D., Coe, H., Allan, J., Visser, S., Slowik, J. G., Furger, M., Prévôt, A. S. H., Lee, J., Dunmore, R. E., Hopkins, J. R., Hamilton, J. F., Lewis, A. C., Whalley, L. K., Sharp, T., Stone, D., Heard, D. E., Fleming, Z. L., Leigh, R., Shallcross, D. E., and Percival, C. J.: The first UK measurements of nitryl chloride using a chemical ionization mass spectrometer in central London in the summer of 2012, and an investigation of the role of $\mathrm{Cl}$ atom oxidation, J. Geophys. Res., 120, 5638-5657, https://doi.org/10.1002/2014JD022629, 2015.

Bannan, T. J., Bacak, A., Le Breton, M., Flynn, M., Ouyang, B., McLeod, M., Jones, R., Malkin, T. L., Whalley, L. K., Heard, D. E., Bandy, B., Khan, M. A. H., Shallcross, D. E., and Percival,
C. J.: Ground and Airborne U.K. Measurements of Nitryl Chloride: An Investigation of the Role of $\mathrm{Cl}$ Atom Oxidation at Weybourne Atmospheric Observatory, J. Geophys. Res.-Atmos., 122, 11154-11165, https://doi.org/10.1002/2017JD026624, 2017.

Borduas, N., Da Silva, G., Murphy, J. G., and Abbatt, J. P. D.: Experimental and theoretical understanding of the gas phase oxidation of atmospheric amides with $\mathrm{OH}$ radicals: Kinetics, products, and mechanisms, J. Phys. Chem. A, 119, 4298-4308, https://doi.org/10.1021/jp503759f, 2015.

Boucher, O., Friedlingstein, P., Collins, B., and Shine, K. P.: The indirect global warming potential and global temperature change potential due to methane oxidation, Environ. Res. Lett., 4, 044007, https://doi.org/10.1088/1748-9326/4/4/044007, 2009.

Butler, J.: Better budgets for methyl halides?, Nature, 403, 260-261, https://doi.org/10.1038/35002232, 2000.

Carlton, A. G., Turpin, B. J., Lim, H. J., Altieri, K. E., and Seitzinger, S.: Link between isoprene and secondary organic aerosol (SOA): Pyruvic acid oxidation yields low volatility organic acids in clouds, Geophys. Res. Lett., 33, 2-5, https://doi.org/10.1029/2005GL025374, 2006.

Crowley, N., Helleis, F., Miiller, R., Moortgat, G. K., Crutzen, P. J., and Orlando, J. J.: CH3OCI: UV/visible absorption cross sections, J values and atmospheric significance, J. Geophys. Res., 99, 20683-20688, 1994.

Deiber, G., George, Ch., Le Calvé, S., Schweitzer, F., and Mirabel, Ph.: Uptake study of $\mathrm{ClONO}_{2}$ and $\mathrm{BrONO}_{2}$ by Halide containing droplets, Atmos. Chem. Phys., 4, 1291-1299, https://doi.org/10.5194/acp-4-1291-2004, 2004.

Derwent, R. G., Middleton, D. R., Field, R. A., Goldstone, M. E., Lester, J. N., and Perry, R.: Analysis and interpretation of air quality data from an urban roadside location in Central London over the period from July 1991 to July 1992, Atmos. Environ., 29, 923-946, https://doi.org/10.1016/1352-2310(94)00219B, 1995.

Derwent, R. G., Davies, T. J., Delaney, M., Dollard, G. J., Field, R. A., Dumitrean, P., Nason, P. D., Jones, B. M. R., and Pepler, S. A.: Analysis and interpretation of the continuous hourly monitoring data for 26 C 2 -C 8 hydrocarbons at 12 United Kingdom sites during, 1996. Atmos. Environ., 34, 297-312, 2000.

Derwent, R. G., Dernie, J. I. R., Dollard, G. J., Dumitrean, P., Mitchell, R. F., Murrells, T. P., Telling, S. P., and Field, R. A.: Twenty years of continuous high time resolution volatile organic compound monitoring in the United Kingdom from 1993 to 2012, Atmos. Environ., 99, 239-247, https://doi.org/10.1016/j.atmosenv.2014.10.001, 2014.

Eigen, M. and Kustin, K.: The Kinetics of Halogen Hydrolysis, J. Am. Chem. Soc., 84, 1355-1361, https://doi.org/10.1021/ja00867a005, 1962.

Faxon, C., Bean, J., and Ruiz, L.: Inland Concentrations of $\mathrm{Cl} 2$ and CINO2 in Southeast Texas Suggest Chlorine Chemistry Significantly Contributes to Atmospheric Reactivity, Atmosphere, 6, 1487-1506, https://doi.org/10.3390/atmos6101487, 2015.

Finley, B. D. and Saltzman, E. S.: Measurement of $\mathrm{Cl} 2$ in coastal urban air, Geophys. Res. Lett., 33, 6-9, https://doi.org/10.1029/2006GL025799, 2006.

Foster, K. L., Caldwell, T. E., Benter, T., Langer, S., Hemminger, J. C., Finlayson-pitts, B. J., and November, A.: Techniques for quantifying gaseous $\mathrm{HOCl}$ using atmospheric pressure ionization 
mass spectrometry, Phys. Chem. Chem. Phys., 1, 5615-5621, doi:Doi 10.1039/A907362k, 1999.

Fuentes, M. J., Font, R., Gómez-Rico, M. F., and Martín-Gullón, I.: Pyrolysis and combustion of waste lubricant oil from diesel cars: Decomposition and pollutants, J. Anal. Appl. Pyrol., 79, 215-226, https://doi.org/10.1016/j.jaap.2006.12.004, 2007.

Ghernaout, D. and Ghernaout, B.: From chemical disinfection to electrodisinfection: The obligatory itinerary?, Desalin. Water Treat., 16, 156-175, https://doi.org/10.5004/dwt.2010.1085, 2010.

Heal, M., Heard, D., Pilling, M., and Whitaker, B.: On the Development and Validation of FAGE for Local Measurement of Tropospheric $\mathrm{OH}$ and $\mathrm{HO} 2$, J. Atmos. Sci., 52, 3428-3441, https://doi.org/10.1175/15200469(1995)052<3428:OTDAVO>2.0.CO;2, 1995.

Heeb, N. V., Zennegg, M., Haag, R., Wichser, A., Schmid, P., Seiler, C., Ulrich, A., Honegger, P., Zeyer, K., Emmenegger, L., Bonsack, P., Zimmerli, Y., Czerwinski, J., Kasper, M., and Mayer, A.: PCDD/F formation in an iron/potassium-catalyzed diesel particle filter, Environ. Sci. Technol., 47, 6510-6517, https://doi.org/10.1021/es400760h, 2013.

Hoffman, R. C., Gebel, M. E., Fox, B. S., and FinlaysonPitts, B. J.: Knudsen cell studies of the reactions of N2O5 and $\mathrm{ClONO} 2$ with $\mathrm{NaCl}$ : development and application of a model for estimating available surface areas and corrected uptake coefficients, Phys. Chem. Chem. Phys., 5, 1780-1789, https://doi.org/10.1039/b301126g, 2003.

Hossaini, R., Chipperfield, M. P., Saiz-Lopez, A., Fernandez, R., Monks, S., Feng, W., Brauer, P., and von Glasow, R.: A global model of tropospheric chlorine chemistry: Organic versus inorganic sources and impact on methane oxidation, J. Geophys. Res.-Atmos., 121, 14271-14297, https://doi.org/10.1002/2016JD025756, 2016.

Huang, B., Lei, C., Wei, C., and Zeng, G.: Chlorinated volatile organic compounds (Cl-VOCs) in environment - sources, potential human health impacts, and current remediation technologies, Environ. Int., 71, 118-138, https://doi.org/10.1016/j.envint.2014.06.013, 2014.

Keene, W. C., Maben, J. R., Pszenny, A. A. P., and Galloway, J. N.: Measurement Technique for Inorganic Chlorine Gases in the Marine Boundary Layer, Environ. Sci. Technol., 27, 866-874, https://doi.org/10.1021/es00042a008, 1993.

Kercher, J. P., Riedel, T. P., and Thornton, J. A.: Chlorine activation by $\mathrm{N}_{2} \mathrm{O}_{5}$ : simultaneous, in situ detection of $\mathrm{ClNO}_{2}$ and $\mathrm{N}_{2} \mathrm{O}_{5}$ by chemical ionization mass spectrometry, Atmos. Meas. Tech., 2, 193-204, https://doi.org/10.5194/amt-2-193-2009, 2009.

Lawler, M. J., Sander, R., Carpenter, L. J., Lee, J. D., von Glasow, R., Sommariva, R., and Saltzman, E. S.: $\mathrm{HOCl}$ and $\mathrm{Cl}_{2}$ observations in marine air, Atmos. Chem. Phys., 11, 7617-7628, https://doi.org/10.5194/acp-11-7617-2011, 2011.

Leather, K. E., Bacak, A., Wamsley, R., Archibald, A. T., Husk, A., Shallcross, E., and Percival, C. J.: Temperature and pressure dependence of the rate coefficient for the reaction between $\mathrm{ClO}$ and $\mathrm{CH} 3 \mathrm{O} 2$ in the gas-phase, Phys. Chem. Chem. Phys., 14, 34253434, https://doi.org/10.1039/c2cp22834c, 2012.

Le Breton, M., McGillen, M. R., Muller, J. B. A., Bacak, A., Shallcross, D. E., Xiao, P., Huey, L. G., Tanner, D., Coe, H., and Percival, C. J.: Airborne observations of formic acid using a chemi- cal ionization mass spectrometer, Atmos. Meas. Tech., 5, 30293039, https://doi.org/10.5194/amt-5-3029-2012, 2012.

Le Breton, M., Bacak, A., Muller, J. B. A., Xiao, P., Shallcross, B. M. A., Batt, R., Cooke, M. C., Shallcross, D. E., Bauguitte, S. J.-B. and Percival, C. J.: Simultaneous airborne nitric acid and formic acid measurements using a chemical ionization mass spectrometer around the UK: Analysis of primary and secondary production pathways, Atmos. Environ., 83, 166-175, https://doi.org/10.1016/j.atmosenv.2013.10.008, 2014a.

Le Breton, M., Bacak, A., Muller, J. B. A., Bannan, T. J., Kennedy, O., Ouyang, B., Xiao, P., Bauguitte, S. J.-B., Shallcross, D. E., Jones, R. L., Daniels, M. J. S., Ball, S. M., and Percival, C. J.: The first airborne comparison of N2O5 measurements over the UK using a CIMS and BBCEAS during the RONOCO campaign, Anal. Methods, 6, 9731-9743, https://doi.org/10.1039/C4AY02273D, 2014b.

Le Breton, M., Bannan, T. J., Shallcross, D. E., Khan, M. A., Evans, M. J., Lee, J., Lidster, R., Andrews, S., Carpenter, L. J., Schmidt, J., Jacob, D., Harris, N. R. P., Bauguitte, S., Gallagher, M., Bacak, A., Leather, K. E., and Percival, C. J.: Enhanced ozone loss by active inorganic bromine chemistry in the tropical troposphere, Atmos. Environ., 155, 21-28, https://doi.org/10.1016/j.atmosenv.2017.02.003, 2017.

Le Breton, M., Hallquist, ̊. M., Pathak, R. K., Simpson, D., Wang, Y., Johansson, J., Zheng, J., Yang, Y., Shang, D., Wang, H., Liu, Q., Chan, C., Wang, T., Bannan, T. J., Priestley, M., Percival, C. J., Shallcross, D. E., Lu, K., Guo, S., Hu, M., and Hallquist, M.: Chlorine oxidation of VOCs at a semi-rural site in Beijing: significant chlorine liberation from $\mathrm{ClNO}_{2}$ and subsequent gas- and particle-phase $\mathrm{Cl}$-VOC production, Atmos. Chem. Phys., 18, 13013-13030, https://doi.org/10.5194/acp-18-130132018, 2018.

Lee, B. H., Lopez-Hilfiker, F. D., Mohr, C., Kurtén, T., Worsnop, D. R., and Thornton, J. A.: An iodide-adduct high-resolution timeof-flight chemical-ionization mass spectrometer: Application to atmospheric inorganic and organic compounds, Environ. Sci. Technol., 48, 6309-6317, https://doi.org/10.1021/es500362a, 2014.

Leu, M.-T., Timonen, R. S., Keyser, L. F., and Yung, Y. L.: Heterogeneous Reactions of HNO3(g) $+\mathrm{NaCl}(\mathrm{s})$.fwdarw. $\mathrm{HCl}(\mathrm{g})+\mathrm{NaNO} 3(\mathrm{~s})$ and $\mathrm{N} 2 \mathrm{O} 5(\mathrm{~g})+\mathrm{NaCl}(\mathrm{s})$.fwdarw. ClNO2(g) + NaNO3(s), J. Phys. Chem., 99, 13203-13212, https://doi.org/10.1021/j100035a026, 1995.

Liao, J., Huey, L. G., Liu, Z., Tanner, D. J., Cantrell, C. A., Orlando, J. J., Flocke, F. M., Shepson, P. B., Weinheimer, A. J., Hall, S. R., Ullmann, K., Beine, H. J., Wang, Y., Ingall, E. D., Stephens, C. R., Hornbrook, R. S., Apel, E. C., Riemer, D., Fried, A., Mauldin, R. L., Smith, J. N., Staebler, R. M., Neuman, J. A., and Nowak, J. B.: High levels of molecular chlorine in the Arctic atmosphere, Nat. Geosci., 7, 91-94, https://doi.org/10.1038/ngeo2046, 2014.

Liu, X., Qu, H., Huey, L. G., Wang, Y., Sjostedt, S., Zeng, L., Lu, K., Wu, Y., Hu, M., Shao, M., Zhu, T., and Zhang, Y.: High Levels of Daytime Molecular Chlorine and Nitryl Chloride at a Rural Site on the North China Plain, Environ. Sci. Technol., 51, 9588-9595, https://doi.org/10.1021/acs.est.7b03039, 2017.

Ma, Y., Brooks, S. D., Vidaurre, G., Khalizov, A. F., Wang, L., and Zhang, R.: Rapid modification of cloud-nucleating ability of aerosols by biogenic emissions, Geophys. Res. Lett., 40, 62936297, https://doi.org/10.1002/2013GL057895, 2013. 
Mandronich, S.: Photodissociation in the Atmosphere Actinic Flux and the Effects of Ground Reflections and Clouds, J. Geophys. Res., 92, 9740-9752, 1987.

Mielke, L. H., Furgeson, A., and Osthoff, H. D.: Observation of $\mathrm{ClNO} 2$ in a mid-continental urban environment, Environ. Sci. Technol., 45, 8889-8896, https://doi.org/10.1021/es201955u, 2011.

Mielke, L. H., Stutz, J., Tsai, C., Hurlock, S. C., Roberts, J. M., Veres, P. R., Froyd, K. D., Hayes, P. L., Cubison, M. J., Jimenez, J. L., Washenfelder, R. A., Young, C. J., Gilman, J. B., De Gouw, J. A., Flynn, J. H., Grossberg, N., Lefer, B. L., Liu, J., Weber, R. J., and Osthoff, H. D.: Heterogeneous formation of nitryl chloride and its role as a nocturnal NOx reservoir species during CalNex-LA 2010, J. Geophys. Res.-Atmos., 118, 10638-10652, https://doi.org/10.1002/jgrd.50783, 2013.

Mielke, L. H., Furgeson, A., Odame-Ankrah, C. A., and Osthoff, H. D.: Ubiquity of $\mathrm{ClNO} 2$ in the urban boundary layer of Calgary, Alberta, Canada, Can. J. Chem., 94, 414-423, https://doi.org/10.1139/cjc-2015-0426, 2016.

Nguyen, T. B., Crounse, J. D., Teng, A. P., St. Clair, J. M., Paulot, F., Wolfe, G. M., and Wennberg, P. O.: Rapid deposition of oxidized biogenic compounds to a temperate forest, P. Natl. Acad. Sci. USA, 112, E392-E401, https://doi.org/10.1073/pnas.1418702112, 2015.

Osthoff, H. D., Roberts, J. M., Ravishankara, A. R., Williams, E. J., Lerner, B. M., Sommariva, R., Bates, T. S., Coffman, D., Quinn, P. K., Dibb, J. E., Stark, H., Burkholder, J. B., Talukdar, R. K., Meagher, J., Fehsenfeld, F. C., and Brown, S. S.: High levels of nitryl chloride in the polluted subtropical marine boundary layer, Nat. Geosci., 1, 324-328, https://doi.org/10.1038/ngeo177, 2008.

Oum, K. W.: Formation of Molecular Chlorine from the Photolysis of Ozone and Aqueous Sea-Salt Particles, Science, 279, 74-76, https://doi.org/10.1126/science.279.5347.74, 1998.

Phillips, G. J., Tang, M. J., Thieser, J., Brickwedde, B., Schuster, G., Bohn, B., Lelieveld, J., and Crowley, J. N.: Significant concentrations of nitryl chloride observed in rural continental Europe associated with the influence of sea salt chloride and anthropogenic emissions, Geophys. Res. Lett., 39, 1-5, https://doi.org/10.1029/2012GL051912, 2012.

Reyes-Villegas, E., Priestley, M., Ting, Y.-C., Haslett, S., Bannan, T., Le Breton, M., Williams, P. I., Bacak, A., Flynn, M. J., Coe, H., Percival, C., and Allan, J. D.: Simultaneous aerosol mass spectrometry and chemical ionisation mass spectrometry measurements during a biomass burning event in the UK: insights into nitrate chemistry, Atmos. Chem. Phys., 18, 40934111, https://doi.org/10.5194/acp-18-4093-2018, 2018.

Riedel, T. P., Bertram, T. H., Crisp, T. A., Williams, E. J., Lerner, B. M., Vlasenko, A., Li, S. M., Gilman, J., De Gouw, J., Bon, D. M., Wagner, N. L., Brown, S. S., and Thornton, J. A.: Nitryl chloride and molecular chlorine in the coastal marine boundary layer, Environ. Sci. Technol., 46, 10463-10470, https://doi.org/10.1021/es204632r, 2012.

Roberts, J. M., Osthoff, H. D., Brown, S. S., and Ravishankara, A. R.: N2O5 oxidizes chloride to $\mathrm{Cl} 2$ in acidic atmospheric aerosol, Science, 321, 1059, https://doi.org/10.1126/science.1158777, 2008.
Sarwar, G., Simon, H., Xing, J., and Mathur, R.: Importance of tropospheric ClNO2 chemistry across the Northern Hemisphere, Geophys. Res. Lett., 41, 4050-4058, https://doi.org/10.1002/2014GL059962, 2014.

Slaper, H., Blumthaler, M., Huber, M., and Kuik, E.: Comparing ground-level spectrally resolved solar UV measurements using various instruments: A technique resolving effects of wavelength shift and slit width, Geophys. Res. Lett., 22, 2721-2724, 1995.

Smedley, A. R. D., Rimmer, J. S., Moore, D., Toumi, R., and Webb, A. R.: Total ozone and surface UV trends in the United Kingdom: 1979-2008, Int. J. Climatol., 32, 338-346, https://doi.org/10.1002/joc.2275, 2012.

Spicer, C. W., Chapman, E. G., Finlayson-Pitts, B. J., Plastridge, R. A., Hubbe, J. M., Fast, J. D., and Berkowitz, C. M.: Unexpectedly high concentrations of molecular chlorine in coastal air, Nature, 394, 353-356, https://doi.org/10.1038/28584, 1998.

Thornton, J. A., Kercher, J. P., Riedel, T. P., Wagner, N. L., Cozic, J., Holloway, J. S., Dubé, W. P., Wolfe, G. M., Quinn, P. K., Middlebrook, A. M., Alexander, B., and Brown, S. S.: A large atomic chlorine source inferred from midcontinental reactive nitrogen chemistry, Nature, 464, 271-274, https://doi.org/10.1038/nature08905, 2010.

Vogt, R., Crutzen, P. J., and Sander, R.: A mechanism for halogen release from sea-salt aerosol in the remote marine boundary layer, Nature, 383, 327-330, https://doi.org/10.1038/383327a0, 1996.

Wang, D. S. and Ruiz, L. H.: Secondary organic aerosol from chlorine-initiated oxidation of isoprene, Atmos. Chem. Phys., 17, 13491-13508, https://doi.org/10.5194/acp-17-13491-2017, 2017.

Wang, W. H. and Finlayson-Pitts, B. J.: Unique markers of chlorine atom chemistry in coastal urban areas: The reaction with 1,3-butadiene in air at room temperature, J. Geophys. Res., 106, 4939-4958, https://doi.org/10.1029/2000jd900683, 2001.

Wang, X., Wang, H., Xue, L., Wang, T., Wang, L., Gu, R., Wang, W., Tham, Y. J., Wang, Z., Yang, L., Chen, J., and Wang, W.: Observations of $\mathrm{N} 2 \mathrm{O} 5$ and $\mathrm{ClNO} 2$ at a polluted urban surface site in North China: High N2O5 uptake coefficients and low ClNO2 product yields, Atmos. Environ., 156, 125-134, https://doi.org/10.1016/j.atmosenv.2017.02.035, 2017.

Wong, J. P. S., Carslaw, N., Zhao, R., Zhou, S., and Abbatt, J. P. D.: Observations and impacts of bleach washing on indoor chlorine chemistry, Indoor Air, 27, 1082-1090, https://doi.org/10.1111/ina.12402, 2017.

Yokouchi, Y., Noijiri, Y., Barrie, L. A., Toom-Sauntry, D., Machida, T., Inuzuka, Y., Akimoto, H., Li, H. J., Fujinuma, Y., and Aoki, S.: A strong source of methyl chloride to the atmosphere from tropical coastal land, Nature, 403, 295-298, https://doi.org/10.1038/35002049, 2000. 